\title{
Social Upheaval, Poverty and the Latvian Demographic Crisis
}

\author{
ALFRED WONG, Social Justice Research Group, \\ Friends of Aboriginal Health Vancouver, Canada
}

\section{Abstract}

Latvia has been suffering a substantial decrease in population since the early 1990s. There appears to have been little or no detailed analysis of the genesis of this decline in population. The major political event occurring at the beginning of the population decline was the rapid transitioning from socialism to capitalism. This study has revealed the causes of severe population decline to be a combination of steadily-declining birth rate, sharply rising high death rate, and mass emigration of people to wealthier European states. The cross-over of birth rate and death rate could be attributed to the tumultuous societal upheavals in the changeover from the socialistic protective-welfare system to a free-market capitalistic economic system. In particular, this traumatic event had probably affected the physical and mental health of many people to result in premature deaths from, among other things, consequential morbidity, accidents, homicides and suicides. Practicable remedies to arrest the continuing trend of precipitous decline in the population might include a) repairing the failures of the current modality of national health care, b) creating higher paying jobs in Latvia to entice prospective young emigrants to stay in Latvia, and c) repatriating of recent Latvian émigrés.

Keywords: economics, emigration, health, Latvia, population, poverty

\section{Introduction}

"No people, No problem" - The Socialist Voice, Dublin, Ireland, October, 2012

The population of Latvia has shown a steady pronounced decline since the restoration of the Republic in 1989-1990. Figure 1 shows the population trend since the 1920s. In the 1945-1990 period of the Latvian Soviet Socialist Republic (LSSR), there was a steady increase in population. Superficially, the increase has been attributed by some researchers to the mass immigration of Russians into Latvia, and to the correspondingly decrease due to the mass exodus of Russians after the end of the LSSR rule (Clemens 1991, Kasekamp 2010, Pabriks and Purs 2002, Plakans 2011, Misunas and Taagepera 1992, Taagepera 1981a, Taagepera 1981b). Some Latvian nationalists have also argued that the mass deportation of Latvians to Russian Far East during the Soviet period had caused irreparable damage to the historical ethnic base of Latvia. But how many 
people were actually deported between 1941 and 1990? The exact figures are largely unknown, with estimates ranging, for example, "about 44,000" (Plakans 2011: 368), "at least 50,000" (Misiunas and Taagepera 1992: 99), and "150,000, including deportation, executions and guerilla warfare" (Clemens 1991: 56). However, this simple depiction does not fully explain the continuing decline during the past 2 decades.

This precipitous decline in population since 1990 is beginning to alarm Latvian demographers and commentators (Anon. 2012a, Anon. 2012b, Anon. 2013a, Anon. 2013c, Behmane 2011, Kolyako 2012c, Kūle 2008, Zukula 2013, Zvidrins 2009). There are ominous suggestions that the extinction of the Latvian nation may even be imminent if no action was taken to reverse the disastrous trend (Anon. 2013f).

Recent discourse on the cause of the population decline includes decreased birth rate (Kūle 2008, Kazāks 2012), lowered fertility rate (Kolyako 2012a), paltry personal economic wealth relative to the $\mathrm{EU}^{1}$ average to cause emigration (Kolyako 2011a, Kolyako 2011b, Kolyako 2012c, Strazds and Grennes 2013) and high suicide rate (Grogan 2006). Suggested remedies include greater financial assistance to families with young children (Kolyako 2012a) and government task force to lure back recent emigrants (Anon. 2012a).

Figure 1. Demographic trend in Latvia

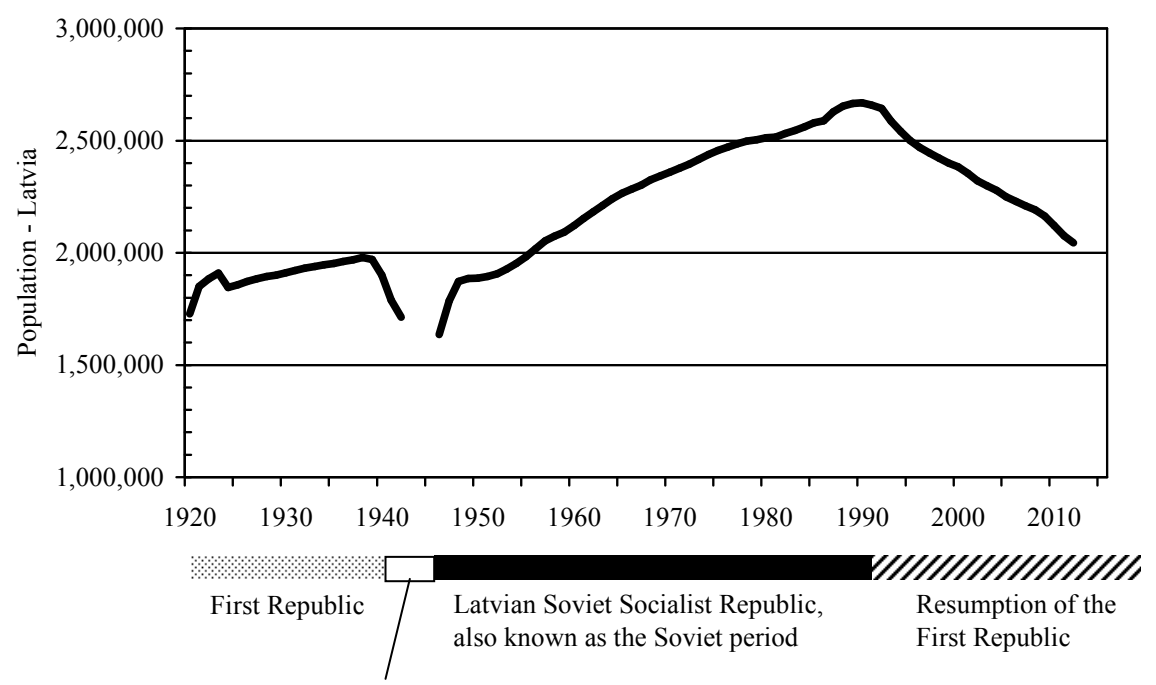

Period of territorial struggle between Latvian factions backed by the Union of Soviet Socialist Republics (USSR) and by the Third Reich (i.e., German National Socialist (Nazi) regime from about 1933 to 1945). Source: CSB (2014) data

There is an acute paucity of literature on the cause(s) of the substantial population decline in Latvia since 1990. In particular, there appears to have been little or no detailed analysis of the underlying social economic factors such as social upheaval and 
poverty triggering this decline in population, during the period of rapid transitioning from Soviet economy to EU capitalism. Moreover, this precipitous decline could not be explained solely by the long-term trend of declining birth rate (which is ubiquitous in most European societies since the 1960s). This study was undertaken to explore the underlying causes of the demographic crisis and possible effective remedies under the prevailing social economic circumstances. The complex confounding factor of ethnicity in the Latvian demographic crisis has been purposely aside for detailed discussion in a separate forthcoming paper (Wong \& Bradley, 2016).

\section{Historical background}

The demography of modern-day Latvia is tied closely to the formation of the Latvian cultural identity since the time of the Northern Crusade in the 12th Century. Both immigration and emigration policies affecting present-day Latvian demography are notably formulated and practiced by dismissing of the 800-year history of serfdom under Germanic hegemony and by focusing on the past 100-year legacy of Soviet communist influence and presence in Latvia. Russophobia (indeed more generally xenophobia) is entrenched in the psyche of contemporary ultra-nationalists inside and outside of government. Such ethno-centric politics could reasonably be expected to have adverse consequences on the present demographic crisis. A review of the key political events of the 20th Century is thus instructive for the interpretation of the emergence and the continuation of the population crisis of the past two decades.

The Eastern coastal region of the Baltic Sea, between $\sim 55^{\circ} \mathrm{N}$ and $\sim 59^{\circ} \mathrm{N}$, was inhibited by migrating tribes belonging to the Indo-European family from about 4000 BCE. By about $1100 \mathrm{CE}$, the identifiable tribal groupings were Latgalians living in the northern side of the lower Dvina River, and Semigallians and Selonians (also known collectively as Letts) living in the southern region of the lower Dvina River (Christensen 1997: 36). The Curonians inhibited the peninsula region between Gulf of Riga and the Baltic Sea. The Livs (also known as Livonians) lived along the coastal area of the Gulf of Riga. It may be noted that there are only about 250 claimants of Livonian ethnicity in present day Latvia; they live in a few scattered villages along the western shore of the Gulf of Riga. Figure 2 shows the principal proto-Latvian tribal groups in about $1200 \mathrm{CE}$. It may be noted that in medieval times, borders are not defined exactly; large rivers, dense forest, and impenetrable swamps usually mark the boundaries of language similarity and/or effective political control.

The approximate timeline of territorial suzerainty of Latvia from 11th Century CE to the early 20th Century CE is illustrated in Figure 3. From the start of the Northern Crusade in $1147 \mathrm{CE}$ to about $1918 \mathrm{CE}$, the suzerainty of region, notably historical Livonia and Courland, changed numerous times among Prussian Teutonic Knights, Sweden, Denmark, Lithuania, Poland, Germany and Russia (Kinder and Hilgemann 1978). From 1720 to 1917, the proto-Latvian nation was a part of the Russian Empire. 
Above all, the Baltic Germans had controlled the clerical and economic life of the region through 800 years. Until the late 19th Century, proto-Latvians were largely serfs with little or no formal education.

Figure 2. Baltic tribes at about $1200 \mathrm{CE}$

Source: adapted from https://en.wikipedia.org/wiki/Livonians

"Latvian cultural re-awakening" apparently began by a small group of local German

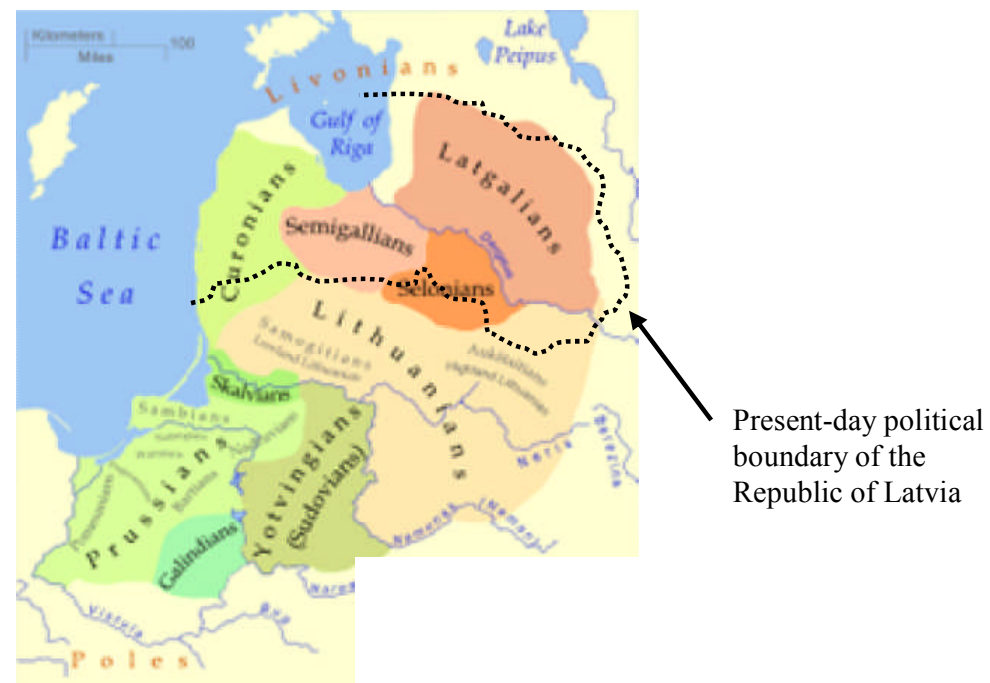

educated elites in $c a$. 1860; they were concerned about the disappearance of the Latvian language under the dominance of the German language within the Russian hegemony (Pabriks and Purs 2002: 2-6, Plakans 2011: 223-234). The first advancement for the independent Latvia was led by Valters and other indigenous socialists in the late 19th Century and the early 20th Century (Ijabs 2012a, Ijabs 2012b). The seed of the struggle between the Germanic and Russian cultural influences among the Latvian independentistes was starting to be formed during that period (Ijabs 2014).

The Republic of Latvia came into existence in 1918 in the chaotic aftermath of the 1917 Russian Revolution. The Latvian Republic was finally recognized in 1921 by the victorious European Powers of WWI. For the next 20 years, the politics of the Latvian state had evolved steadily into a dictatorship under the control of Kārlis Ulmanis (Kasekamp 2010) pitting the socialists (Bolsheviks) backed by the USSR against the fascists backed by the Third Reich. In the short-lived 1939 Ribbentrop-Molotov Pact, resurgent Germany had secretly assigned Latvia to the Soviet sphere of influence. Nevertheless, the Latvian Republic ended abruptly in 1940 with the invasion of the German armed forces ${ }^{2}$. 
Figure 3. Time line of contested suzerainty within present-day boundary of Latvia to 1940

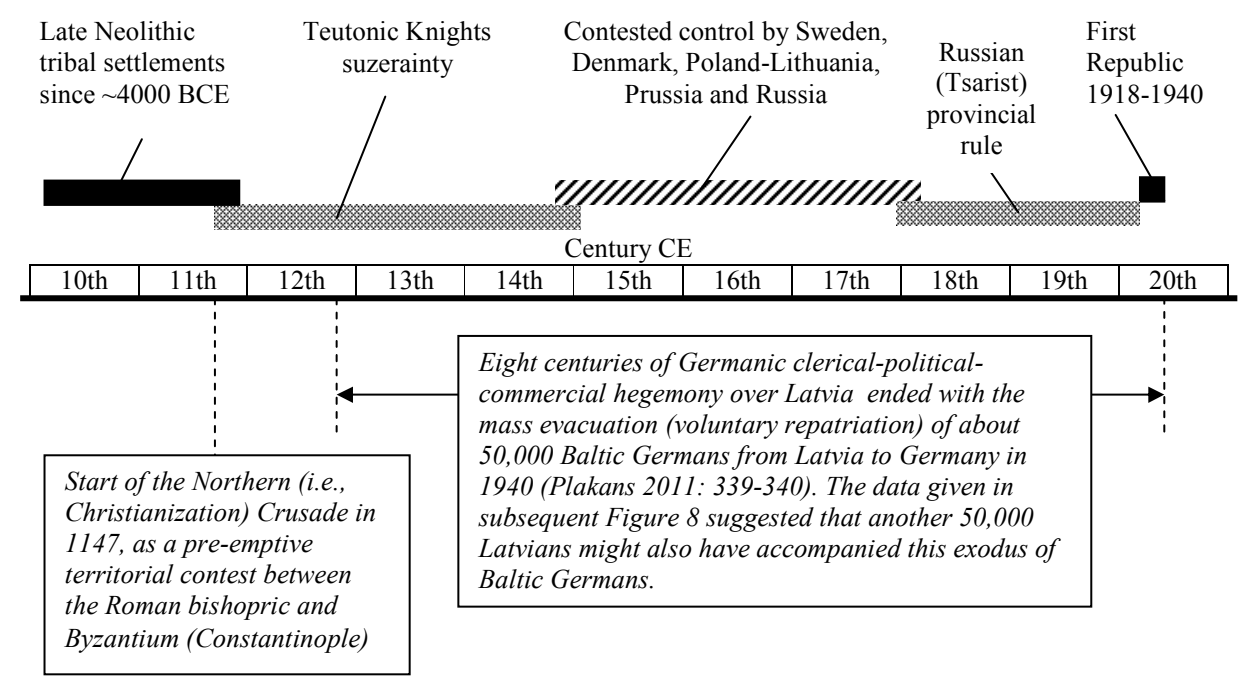

The post-war Soviet sphere of influence in Eastern Europe including the Baltic States was agreed secretly by all parties concerned at the Tehran Conference in late 1943, and confirmed at the Yalta Conference in 1945 (see, for example, Riasanovsky 1984: 523-524). In essence, each victorious power had basically staked out its desired sphere of influence and hegemony. Curiously, this fact of history is rarely discussed by many post-1990 Latvian historians. At the conclusion of the WWII in Europe, the Soviet Union took previously-agreed political control of Latvia which led subsequently to the establishment of the LSSR as a constituent republic of the USSR. It is evident that the existence of the LSSR has shaped and has continued to shape the present public policy of Latvia today (Anon. 2014). Indeed only the most recent period of foreign domination (i.e., the Soviet era) remains prominently in the political consciousness of post-1990 ruling regimes.

The 1918 Latvian Republic was formally restored in 1991. The accession of Latvia into the European Union was in 2004.

\section{Study data and methods}

The demographic data published by the Latvian Central Statistics Bureau (CSB) were used extensively. The population reported denotes residents present in Latvia at the time of the census or estimate. Additional demographic data for comparison were sourced from EUROSTAT and pertinent national statistics agencies.

The public-domain data were assumed to be accurate and truthful. It should be cautioned however that official statistics are known to be altered, distorted or even suppressed surreptitiously for national, political and economic reasons ${ }^{3}$. Such practice is widespread. 
The formulae used for the estimation of historical annual net migration are based on the well-known "cohort-component" method for population projection (ONS 2013). Specifically,

$\mathrm{Cn}=\mathrm{Bn}-\mathrm{Dn}$

where $\mathrm{Cn}=$ natural change for the $\mathrm{nth}$ year

$\mathrm{Bn}=$ crude births reported for the nth year

$\mathrm{Dn}=$ crude deaths reported for the nth year

Pne $=$ Pno $+\mathrm{Cn}$

where Pne $=$ population estimate at year $($ December 31$)$ end $=$ population estimate at start (January 1) of the following year

Pno $=$ population reported at nth year start (January 1$)$

$\mathrm{Mn}=$ Pnf - Pne

where $\mathrm{Mn}=$ net migration for the nth year

Pnf $=$ population reported for the start of the following $(n+1)$ year

The $\%$ rate of crude births (or deaths or migration) is calculated as $100 \mathrm{x}$ (crude births/ population) for any specified year. The rate could also be expressed as "numbers per 1000 persons".

It may be noted that the estimated net migration does not describe the ethnic or age mix of people entering or leaving Latvia. Moreover, with the inclusion of Latvia into the border-less Schengen travel Agreement in December, 2007, the exact number of Latvians departing for or entering from other EU member states became effectively less recordable. Thus, the deployment of Equation (3) serves only as the best-available proxy to quantify the net migration of residents in any one year. The robustness of data deployed in this study is summarized in Table 1 . The weakest link is clearly the estimate of inflow or outflow migration. The exception is that the Latvian migration data given prior to 1990 could be considered to be accurate as the movement of people during Soviet times was highly monitored and regulated. However, for the sake of uniformity, the archival LSSR pre-1990 data set was not used in the present estimation of migration.

Table 1. Robustness of population data used

\begin{tabular}{|l|l|l|}
\hline & \multicolumn{1}{|c|}{ Census year } & \multicolumn{1}{c|}{ In between census year } \\
\hline Population & Direct count & $\begin{array}{l}\text { Projected from data of last census } \\
\text { year }\end{array}$ \\
\hline $\begin{array}{l}\text { Vital statistics (births and } \\
\text { deaths) }\end{array}$ & Exact & Exact \\
\hline Migration & $\begin{array}{l}\text { Calculated from census-year } \\
\text { population count and vital statistics }\end{array}$ & $\begin{array}{l}\text { Calculated from projected } \\
\text { population and vital statistics }\end{array}$ \\
\hline
\end{tabular}




\section{Results}

\section{Demography}

The population of Latvia has been and is still declining steadily since the end of the Soviet period (Figure 1). Although the decline during the first half of 1990s, may be due mostly to the substantial exodus of Russian expatriates, the steady decline in the national population since that time has remain unabated. Interestingly, Taagepera (1981b) was already lamenting about the population crisis in Latvia on the basis of pre-1980 vital statistics. The worsening situation was still 10 years hence.

\section{Natural change}

The present trend of population decline appears to be exacerbated by the longer term decline in the (crude) birth rate and concomitant substantial increase in the death rate. As given in Figure 4, the distinctive cross-over of crude birth rate and death rate occurred in Latvia at about the time of the rapid transition from Soviet socialist system to the free-market capitalistic system. Analysis of the natural change alone, i.e., simple arithmetic difference between crude birth rate and death rate as calculated using Equation (1), is insufficient to provide an accurate view of the prevailing demographic situation. Both crude birth rate and death rate must be considered explicitly in the context of prevailing societal circumstances. It is evident that no matter how high the birth rate might be, the population number will decline if the death rate exceeds the birth rate by a significant margin consistently over a period of time. It is recognized that consistent low birth rate will affect the age distribution of the population in future years, if the death rate remained constant. Accurate prediction of age distribution in future years is problematic as such critical factors as fertility rate and premature (natural or not) death rate are largely unknown.

Twenty years later, the Latvian society is still being affected by the fallout of the chaos of the 1990-1995 transition. The death rate has remained substantially higher than the crude birth rate. The overall social cost of transition has been considerable. For example, suicide rate rose substantially from 28.6 per 100,000 in 1991 to 36.4 per 100,000 in 1997 (Rejevska 2005). In the Soviet era, the population relied customarily on State-provided social and economic services. Health care and education were free. Full employment was essentially the norm. In essence, everyone was taken care of, albeit somewhat meagre in many instances. Despite many shortcomings and abusive excesses of the late socialist system, no one was starving, and no one was homeless. As a means of re-population after the substantial population loss during the Great Patriotic War (syn., WWII), the USSR was promoting family formation aggressively with an advanced social assistance system including financial and non-financial bonuses for new family additions, early childhood care, etc. (See, for example, Hecht 1986). 
Figure 4. Latvian crude birth and death rates

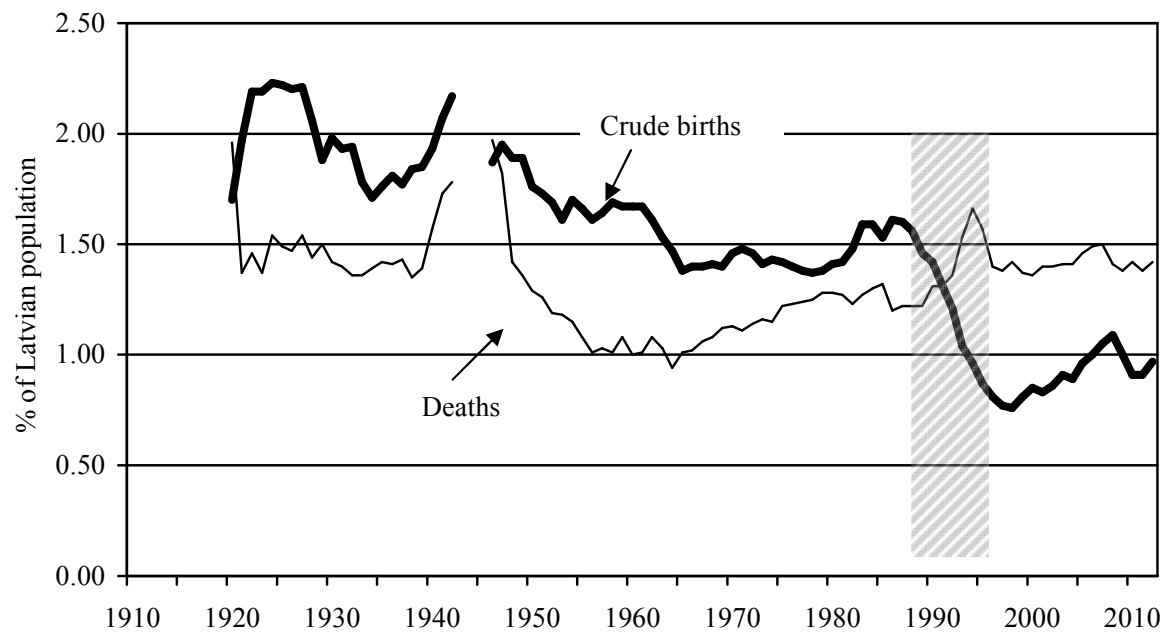

Source: CSB (2014) data

In the changeover from the Soviet era, this structure was abruptly terminated as Latvia and most other former republics were rushing invariantly to embrace free-market capitalistic system to varying extent. In Latvia, State-owned industries built up during the Soviet period were suddenly destroyed by abandonment and/or by privatization. Mass unemployment resulted. In the new free-market capitalistic, some people became very rich instantly with the influx of speculative funds from the "free West" while many (especially older people) were left behind socially and economically. This sudden destruction of societal structure has caused to an increase in alcohol and drug abuse, homelessness, etc. which subsequently led to a sharp rise in premature deaths from consequential morbidity, accidents, homicides and suicides. It does not appear that the perpetuators of this structural change abetted enthusiastically by western Europe and others had fully considered the subsequent adverse effects on the people at large. In retrospect, these human catastrophes could have been avoided if there had been less frenzy and exuberance during the period of pursuit of "freedom, prosperity and democracy".

Figure 5 shows the presence of the same cross-over of birth and death rates in neighbouring Estonia and Lithuania. Except during the 1917 collapse of Romanov rule and the 1940 Winter War, there was no similar cross-over pattern in Finland. It is pertinent to note that the proposition advanced by Pritchett and Viarengo (2012) about the relationship between prosperity and new personal choices available to degrade irrevocably the societal percept of having children as cultural and social validation. As exemplified by Finland with one of the most generous support schemes for family formation among EU member states, improving financial support for family formation in Latvia would probably not result in arresting the continued decline in crude birth rate. 
Recent slight increases in Europe-wide birth rates have been discussed by, among others, Hoem (2005) and Bongaarts and Sobotka (2012). However, these analyses appear to have ignored the confounding effect of the changing ethnicity of the base population as caused by the influx of non-European immigrants into Europe. For example, Turkish-ethnic residents now account for nearly 10 per cent of the present population in Germany. In France, African and Arabic population might be as much as 20 per cent of the total population ${ }^{4}$. The percept and practice of family formation of these ethnics group (perhaps even at the second generation level) could reasonably be expected to be very different from those of contemporary indigenous Europeans.

The statistical data given in Figure 6 suggest the impact of this transitional event was also evident on the steep decline in crude birth rate of other former republics of the USSR. On its own, rising death rate is not necessarily alarming to affect population status. The situation becomes critical from the perspective of population replacement only when the birth rate is also declining. Interestingly, only republics which are predominately Slavic had also a concomitant substantial rise in the death rate of all causes. One plausible explanation for this notable occurrence is the different social cultures of Slavic (Christian) and non-Slavic (Islamic) communities. In (Orthodox) Christian societies, i.e., Belarus, Russia and Ukraine, alcohol (over)consumption is an accepted social practice which could be an additional factor of premature mortality. In contrast, in Islamic culture, consumption of alcohol is harām ${ }^{5}$. Moreover, unlike Orthodox Christian ambiguity about suicide, Islam views suicide to be a sinful act ${ }^{6}$. Furthermore, the historic high birth rates in former republics of the USSR with substantial Moslem population may be rooted in religious belief and cultural suspicion. Roudi-Fahimi (2004) had observed additionally that there is a widespread resistance to the adoption of interventionist birth control method among the Moslem communities because of the deep suspicion that it is a grand scheme perpetuated by the "Christian West" to decrease the political influence of Islam by reducing the Moslem population. It is possible that citizens of the "less industrialized and less urbanized" former republics of the USSR may have also encountered generally less stresses of modern lifestyle changes to result in little or no change in death rate. Nevertheless, the recent historical evidence suggests social upheaval to be the root cause of the present demographic crisis in Latvia as well as in other similar (Christenic) societies of the former USSR.

It is interesting to note in Figure 6 that the death rate (of all causes) was beginning to rise appreciably already in Belarus, Russia and Ukraine in about 1980. These countries were the leading members of the USSR. In comparison, the rise in death rate between 1980 and 1990 in Latvia (in Figure 4). Estonia (in Figure 5) and Lithuania (in Figure 5) was somewhat less pronounced. It is generally recognized that there was appreciable concomitant decline in the public health and health care system in constituent republics of the USSR in the decade prior to 1900, the origins of which are not fully clear. 
Figure 5. Crude birth rate and death rate in neighbouring Baltic States

Estonia

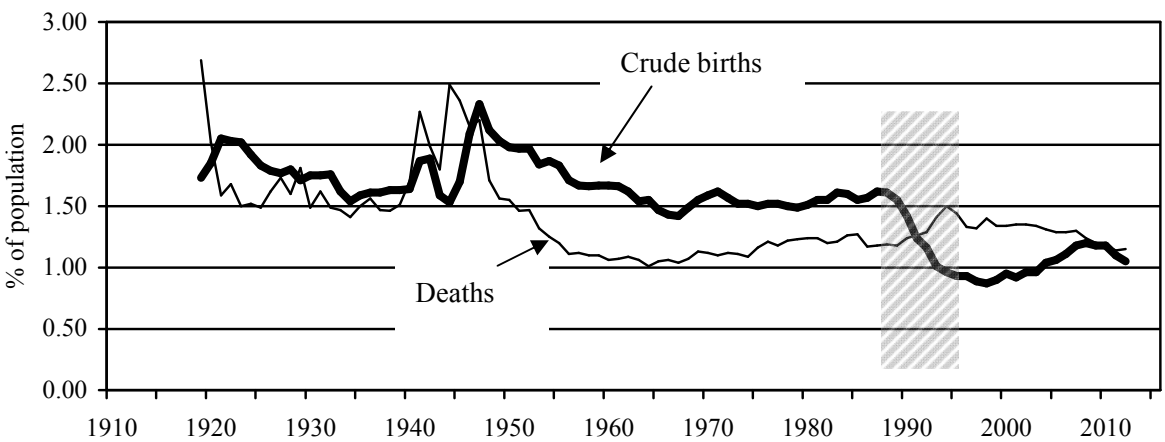

Lithuania

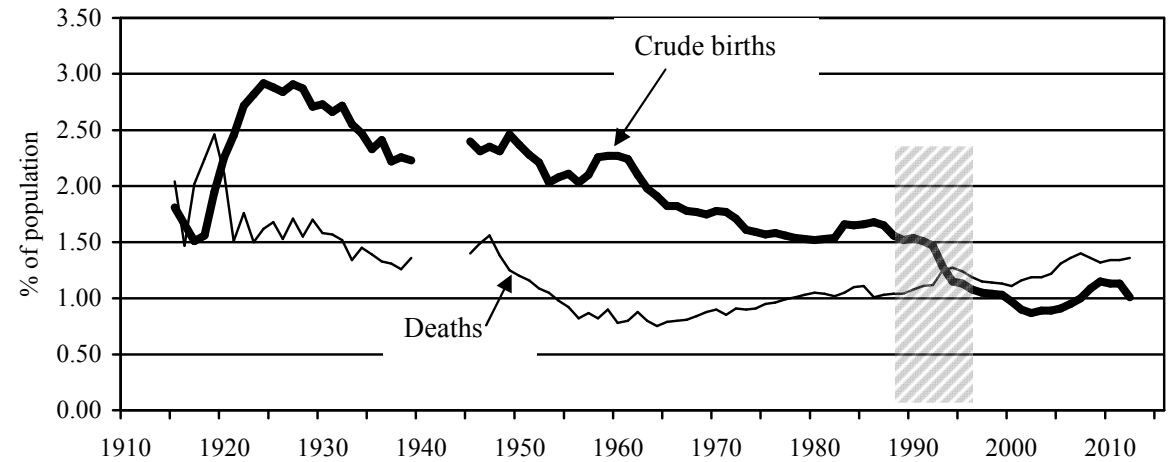

Finland

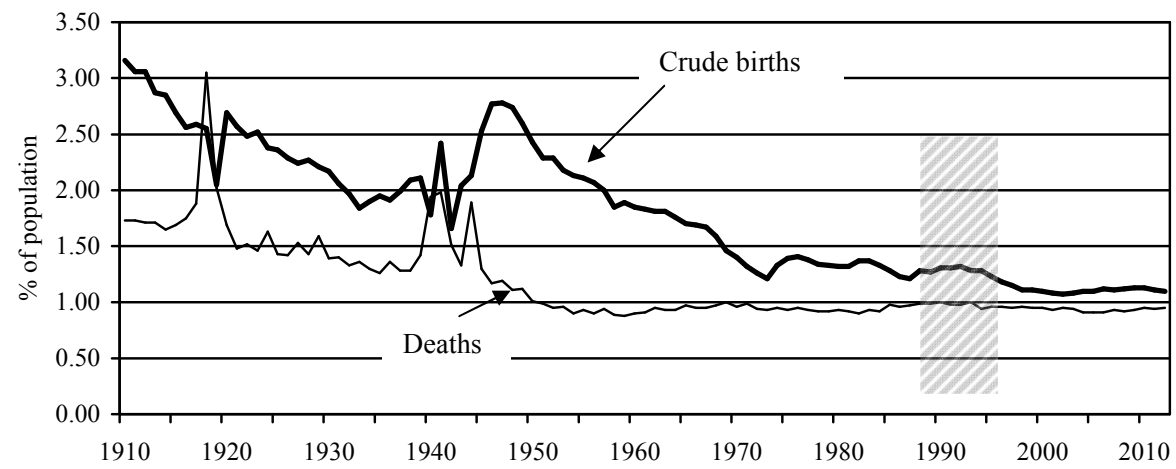

Source: Statistics Estonia (2014) data; Statistics Finland (2014) data; Statistics Lithuania (2014) data 
Figure 6. Crude birth rate and death rate of selected former republics of the USSR
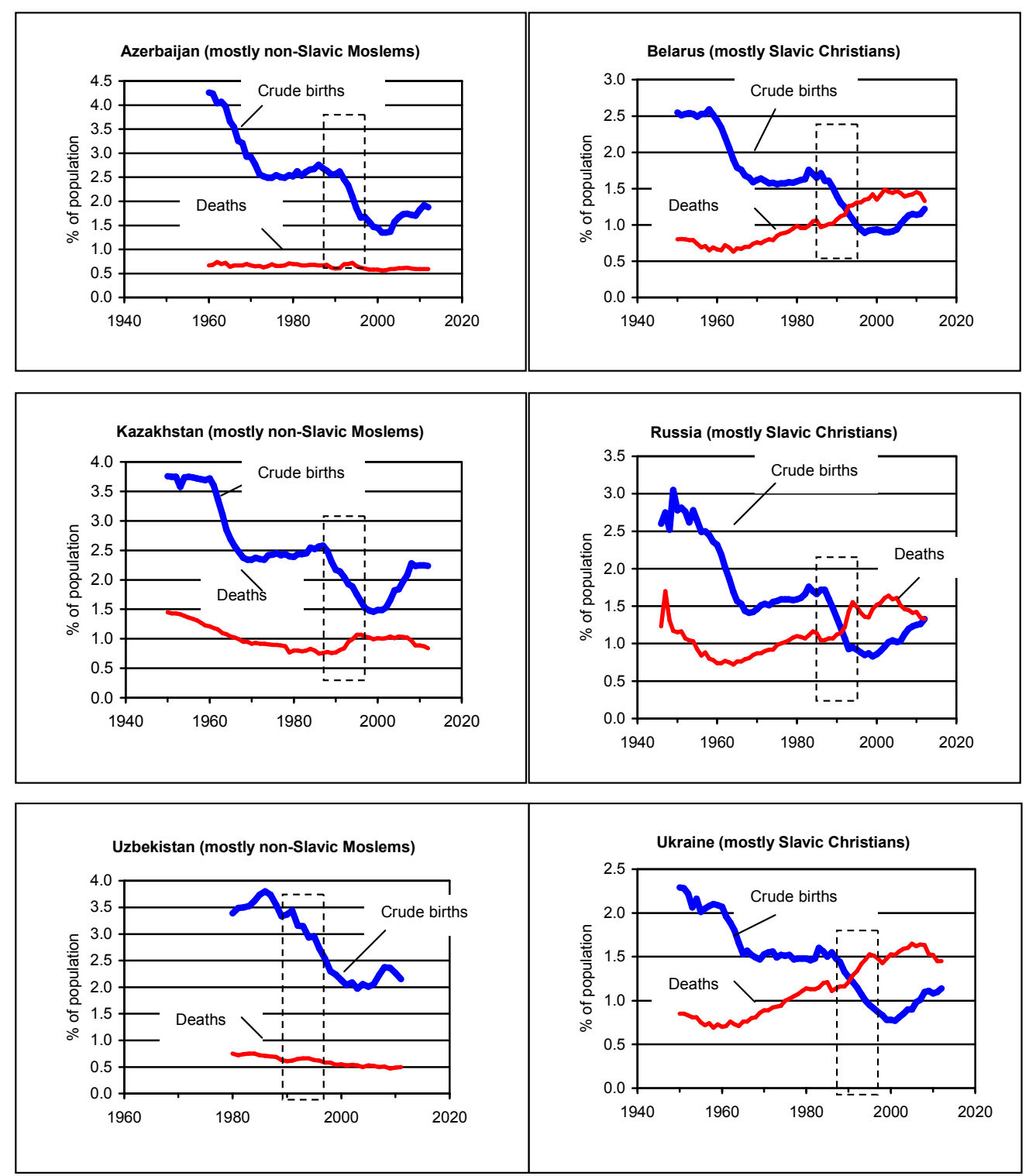

Note: The vital statistics of several other former republics of the USSR were not shown because of substantial changes in national boundaries arising from wars (i.e., Transnistria from Moldova, and Abkhazia and South Ossetia from Georgia), natural disasters (i.e., Armenia) or the lack of reliable statistical data (i.e., Kyrgyzstan, Tajikistan and Turkmenistan).

Source: Published data of various national statistical agencies 
In a study of selected Eastern European countries after the collapse of the USSR, Várnik (2012: 159-164) and Kõlves et al. (2013) had concluded that the adverse changes in suicide rates to be related to the socioeconomic disruptions. Rechel et al. (2013) have reported large decreases in life expectancy in the Commonwealth of Independent States since the 1990s. However, in an earlier study about Latvia, Rancans et al. (2001) did not find any relationship between rapid changes in suicide rates, and demographic and socioeconomic factors. Increase in suicide rate is perhaps only one element of higher reported mortality arising from the traumatic destruction of the societal structure. This adverse outcome could not have predicted readily from the retrospective analysis of the slow-moving trend in life expectancy (at birth) of the general population in Latvia as well as in other former republics of the USSR.

Through the prism of the reference frame of "superior western democracy", Mackenbach (2013) and Mackenbach et al. (2013) contended that living under democracies afford inherently healthier lives. This proposition would appear to be somewhat unfounded as it does not account for the more important factor of government policy priorities on national health care, regardless of whether a State is democratic or not. Witness the case of Cuba in which the World Heath Organization consistently ranks it to be at top level of health care in the World. And yet the democracy modality of Cuba is distinctly different from that of the European Union, for example. Mackenbach and co-researchers did however concede broadly that the substantial sudden changes in political conditions had also caused unexpected decline in the health of the population in central and eastern European states which were not formally members of the USSR. But in the absence of specific societal context, there is no reason why unrestricted freedom (i.e., new politics) would provide higher healthy life expectancy.

As shown in Figure 7, the amount and effectiveness of money spent on national health care in the context of government policy priorities would intuitively be a more critical determinant of good health. Note that "unfree" Cuba spent nearly 10 times less on health care than the "free" USA on a per capita basis, and yet the health outcome as depicted by life expectancy is nearly the same. This comparison suggests that higher expenditure in health care, for example beyond the pivotal point of Cuba, does not necessarily result in significantly higher life expectancy. The correlation between life expectancy (i.e., how long a person might expect to live) and death rate (i.e., a direct record of the expiration of life) is tenuous at best. Ainsaar (2011) had addressed the issue of population changes on the basis of prevailing life expectancy which is calculated from numerous temporal qualitative and quantitative variables such as employment, financial income, expected and real quality of life, etc. Death rate or absolute number of deaths might have been a better (and simpler) means to assess population changes.

Similarly, Minagawa (2013) concluded that people living in "countries where corruption, restriction of freedom, and violence are prevalent spend fewer years in good health". Some of these highly-publicized negative attributes of the Eastern European states and former USSR might just have been circumstantial correlates. In the case of 
corruption, it has been reported to be also widespread in the "healthy" EU (see, for example, European Commission 2014). Corruption is a complex issue arising from, among other things, poverty perpetuated by neocolonial free-market liberalism (see, for example, Wong and Gomes 2014), psychopathic pursuit of corporate profit (Wong and Hallsworth 2013, Hallsworth and Wong 2015), and geo-political hegemony through bribery (Wong and Gomes 2014).

The excesses committed in the restructuring of the Latvian society during the 1990s were probably driven to a certain extent by previously latent nationalist sentiment in the severe reaction to the 45 years of the Soviet period. Rampage against "everything Russian" was in vogue. Perhaps the seduction of promised EU largesse had also played a vital role in triggering the societal dismemberment and subsequent human catastrophes. The possible dire consequence of these political changes did not appear to have been considered thoroughly by domestic and foreign parties in power. Regrettably for Latvia, this crisis of population decline continues unabated nearly 25 years after the demise of the Latvian Soviet Socialist Republic.

Figure 7. Health care spending and life expectancy in 2008 (number of countries surveyed)

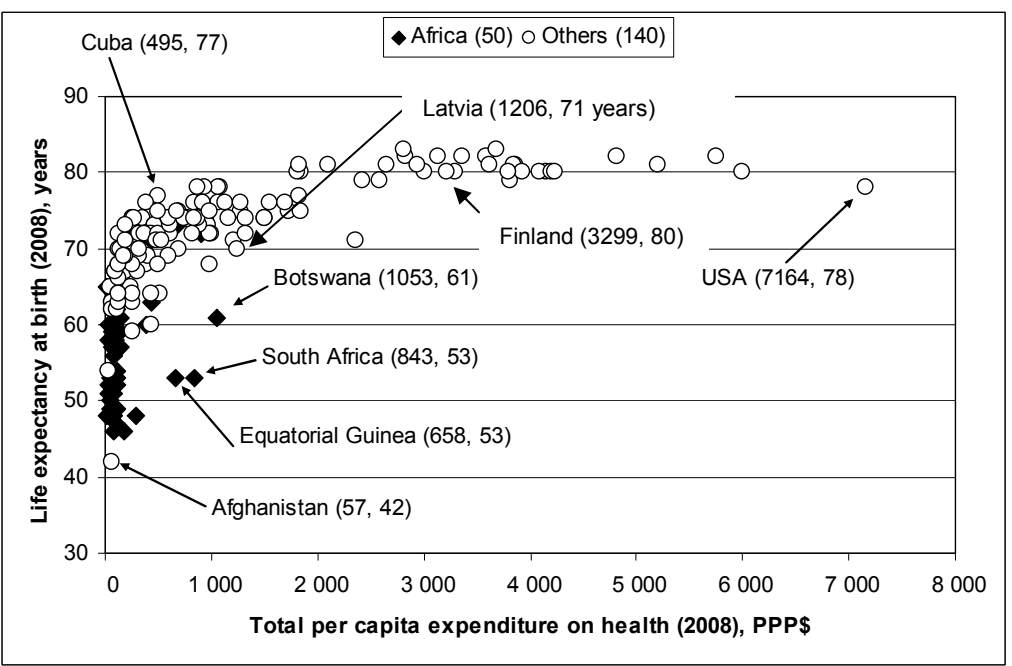

Sources: Adapted from Wong and Gomes 2014

\section{Emigration}

It is widely known that there has been significant emigration of citizens, especially after the accession of Latvia to the EU in 2004. The cumulative emigration since the Latvia accession to the EU (i.e., loss of population between 2004-2012) was $163,759(\sim 20,469$ each year on average). Ireland and the UK are the largest recipients of Latvian émigrés 
(Göler et al. 2014). It is interesting to compare this emigration figure to the cited highest loss of "150,000" Latvian nationals during the 45-year Soviet period. The calculated average loss in the latter case would have been $\sim 3,300$ annually.

Figure 8 shows the trend of net migration since 1920. It may be noted that for reasons of ethno-centric politics, there is (and has been) no significant immigration since the early 1990s. Interestingly, there have been recent accusations that the official statistics may have purposely under-reported the Latvian exodus (Anon. 2013d). Nevertheless, if this pattern was repeated successively, the obvious net result, i.e., sum of deaths and emigration being greater than births, is a continuing precipitous fall in population.

Figure 9 shows that the cross-over trend of crude births and deaths, in absolute numbers, of residents of Latvia during the period of 1970-2010. Note that the crossover point is the same as that given previously in Figure 4. The straight-line correlation coefficient, $r^{2}$, between crude births and crude birth rate, as well as between deaths and death rate, is 0.94 (not shown). Note that in the post-1990 era, the number of crude births year-by-year remained well below that of deaths. This persistent gap between crude births and deaths of cohorts who have not emigrated from Latvia has a considerable impact on population size. It is evident that the present demographic crisis is continuing regardless of the method of calculation used.

In addition to the previously-discussed decline in health care in the post-1990 era in transitioning from a socialistic economy to a capitalistic economy, there is the unknown factor of possible differential access to quality health care in the post-1990 era. For example, do older non-citizens ${ }^{7}$, i.e., mainly Russian-speaking people who had come to reside in Latvia after 1940, have less access to quality health care? Has there been systemic discrimination in the delivery of quality health care to non-citizens as a class of residents? One could only speculate about the actual situation as no reliable data are available presently to prove or disprove this politically highly sensitive matter (Wong \& Bradley, 2016).

Figure 8. Net migration from Latvia

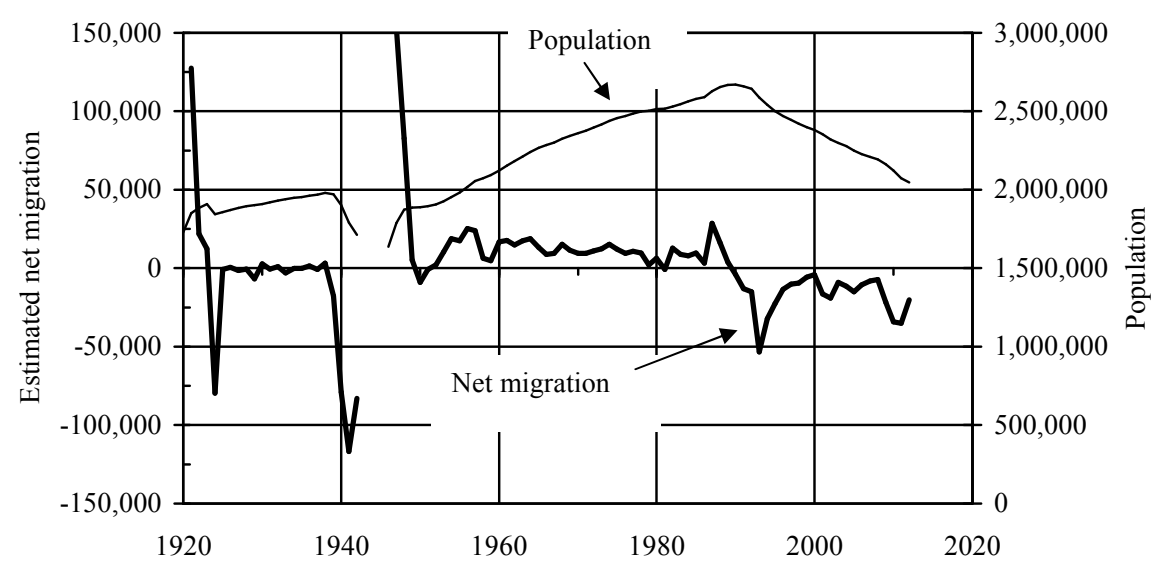


Figure 9. Reported crude births and deaths of residents of Latvia, 1970-2010 inclusive

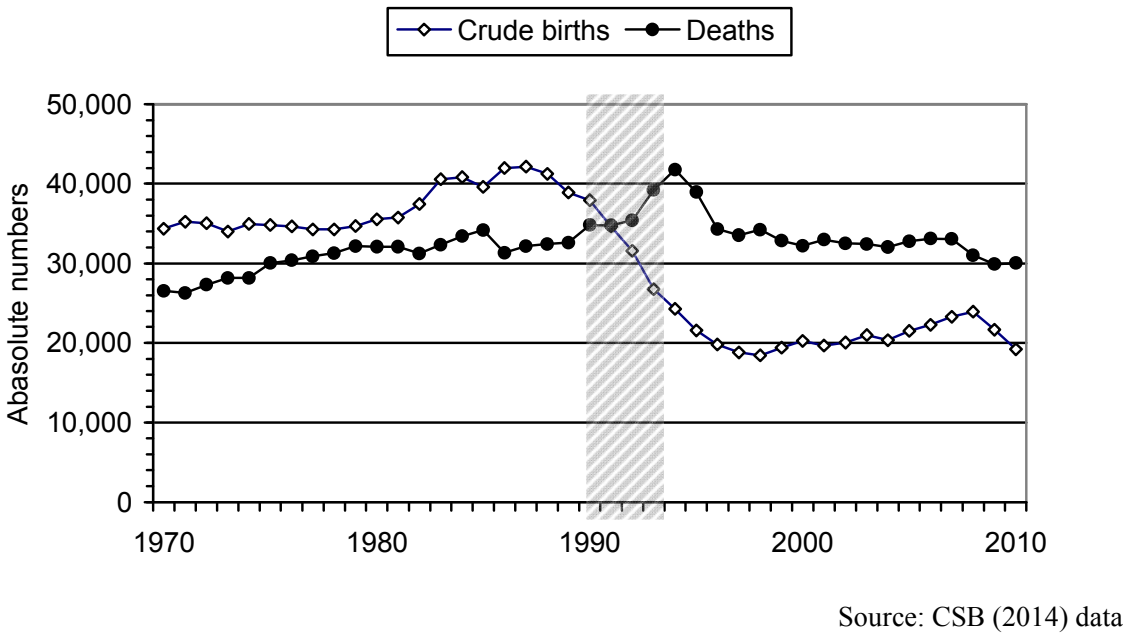

It is recognized that emigration has a long term negative effect on the remaining population in future years, especially if the majority of emigrants was of child-bearing age. Thus, the birth rate of the remaining population could be adversely affected. Figure 10 shows the general lack of correlation between migration and crude births, without considering a) any possible time-delayed effects between migration and births, and b) specific age distribution of migrants over time. The data were not pooled for analysis because the circumstances pertaining to immigration in the pre-1990 period were very different from those pertaining to emigration in the post-1990 era. It is possible that the death rate might be shifted higher statistically because with younger people emigrating, there would be disproportionately more remaining people at the "dying age". However, such a shifted higher death rate might be of minor significance in view of the observed long-term trend of (high) number of deaths of remaining residents, as shown in Figure 9.

Figure 10. Relationship between migration and crude births, in absolute numbers, on a yearly basis

- Pre-1990 o Post-1990

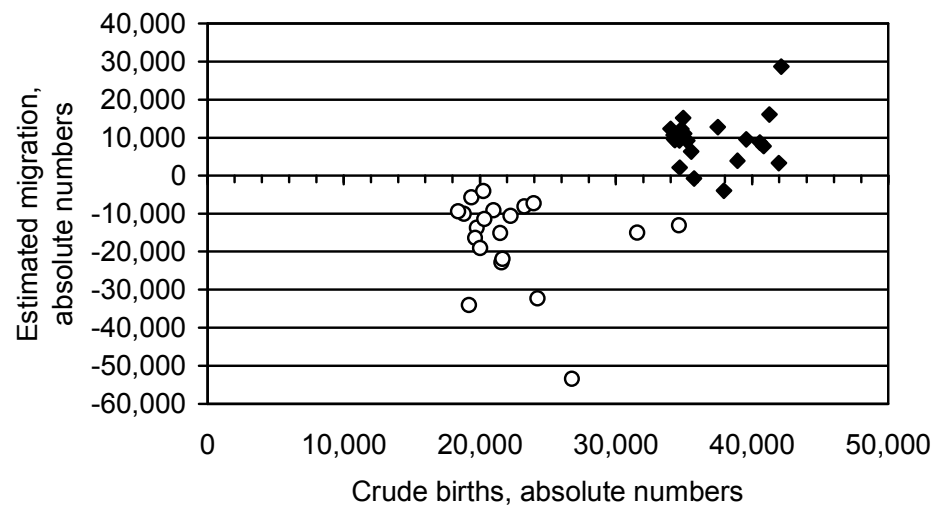


In ethno-centric politics, population loss due to emigration is of less concern to the ultranationalists inside and outside of government; their viewpoint is that emigration should be encouraged as a facile means to purge Russian-speaking Latvians of all ages from Latvia. This approach has evidently nothing to do with economics or family policies. It may never be known if such ethnic-based emigration statistics were collected officially but not published openly for political reasons (Wong \& Bradley, 2016).

What causes this mass emigration in the new Latvia? Emigration in modern times could be attributed generally to only 4 major causes, viz., war, famine, pestilence and poverty. There has been no major war, famine or pestilence in Latvia since 1945. Latvians emigrate largely to other wealthier northern EU states in search of a more prosperous future. Other EU states such as Ireland and Portugal have a similar pattern of similar mass emigration of people during the current period of high unemployment rate arising from the recent collapse of the EU economy. For example, approximately 400,000 out of a base population of about 11 million have left Portugal since 2008 in search of a better life elsewhere (Lyulko 2014). But how poor are Latvians quantitatively in comparison to Irish in the context of mass emigration? The classical cost comparison of standard "food basket" or "housing" is somewhat meaningless as the acceptable (or tolerable) lifestyles of Latvians are very different from those of Irish. Thus, the "purchasing power parity" method was not considered to be applicable for this and other economic comparisons. A veritable test would be to compare the relative cost of "vacation air fare" between, for example, Riga and Dublin. The premise is that everyone is entitled to the same vacation opportunity. The comparison of the "return airfare as a \% of average annual gross earning" in Table 2 suggests Latvians to be about 3 times poorer than Irish.

Table 2. Comparative poverty in Latvia and in Ireland

\begin{tabular}{|l|c|l|c|c|}
\hline & $\begin{array}{c}\text { Nominal annual } \\
\text { gross earning, } \boldsymbol{\epsilon}\end{array}$ & $\begin{array}{c}\text { Travel routing } \\
\text { via Frankfurt (a) }\end{array}$ & $\begin{array}{c}\text { All-in return } \\
\text { airfare, } \boldsymbol{\epsilon}\end{array}$ & $\begin{array}{c}\text { Air fare \% of } \\
\text { annual gross } \\
\text { earning }\end{array}$ \\
\hline Irish vacationer & 40,000 & Dublin $\rightarrow$ Riga $\rightarrow$ Dublin & 487.50 & 1.22 \\
\hline Latvian vacationer & 10,000 & Riga $\rightarrow$ Dublin $\rightarrow$ Riga & $358.17(\mathrm{~b})$ & 3.58 \\
\hline
\end{tabular}

Notes:

(a) One-week vacation starting on July 6, 2013 and ending on July 13, 2013; Lufthansa (a non-budget airline) first early morning departures only.

(b) Conversion from LVL 251.79, at €1.00 = LVL 0.703 (fixed rate since 1999). Latvian Lat (LVL) was the national currency from about 1990 to 2013. Source: Wong 2013 
Figure 11 shows the average annual gross earnings in industry and services of selected groups of EU member states. In order to reach wage parity with the northern EU member states by 2022, a sustained annual wage increase of about $17 \%$ in Latvia would be required, on the basis an example constant $2 \%$ annual growth in wages of northern EU states. It is obvious that the Latvian wage-parity target could not be attained at such an annual intense growth rate. Pursuit of Latvians to earn higher wages in wealthy EU states would persist regardless of the acceptable or tolerable (low cost) lifestyles in their homeland, in the era of "freedom to travel or work" in the new EU. This modality of economic migration is not totally different from that described elsewhere (see, for example, Wong and Gomes, 2012).

Figure 11. Wage gap between Latvia and selected 'wealthy' EU-15 member States

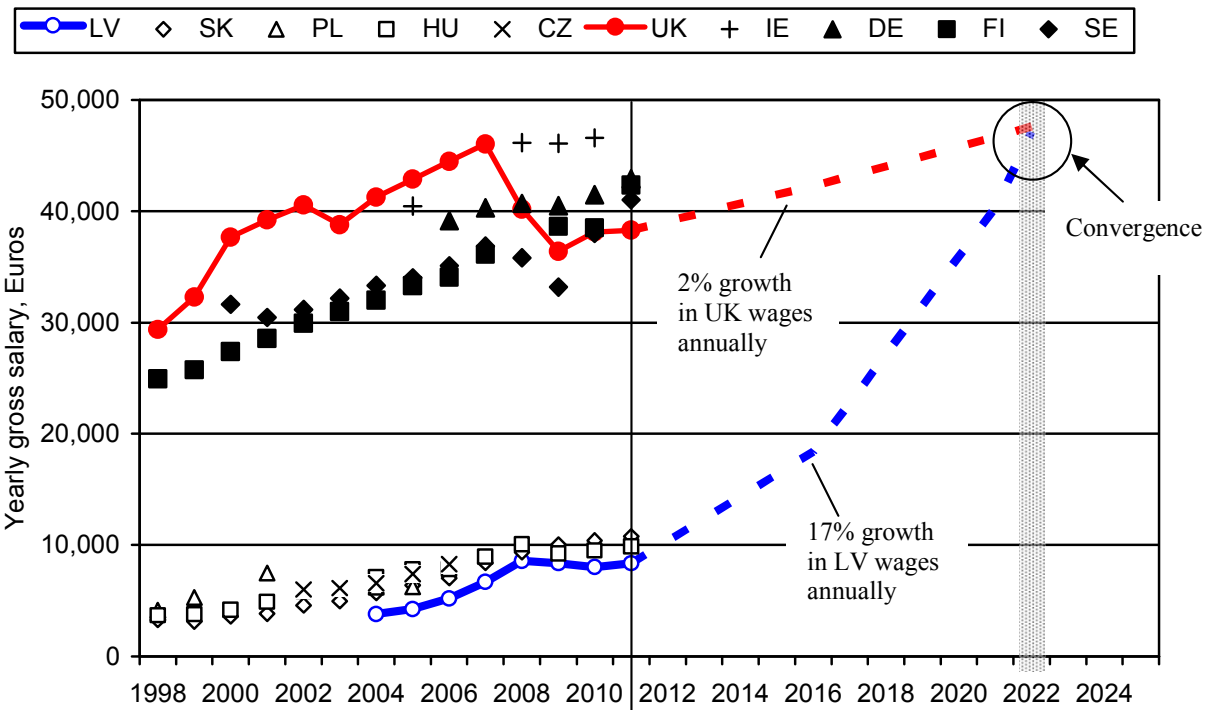

Source: EUROSTAT (2014) data

It is instructive to compare the minimum wage level in Latvia with the UK and Ireland, the preferred destinations of most Latvian emigrants. As shown in Figure 12, the minimum wage of a teacher in Latvia is substantially less than that of an unskilled labourer in Ireland or the UK. This severe economic disparity would logically induce the educated Latvians to emigrate under the "freedom to travel and work" regime of the new Europe. As an escape from poverty, some Latvian young women have emigrated to Ireland to participate in fake-marriage schemes as a quick means of earning a higher income than that possible in Latvia (Katz 2011, Cahill 2013). An economic solution to this problem is obviously needed. Note also that the official wage of a Latvian Minster of State is only slightly higher than the minimum wage of an Irish or British unskilled worker. This 
extreme disparity of earnings from employment creates one of the essential conditions for corruption among government officials of all ranks. Indeed, Latvia is ranked among the most corrupt countries in the European Union (Transparency International 2013).

Figure 12. Statutory minimum monthly salary (before any deductions)

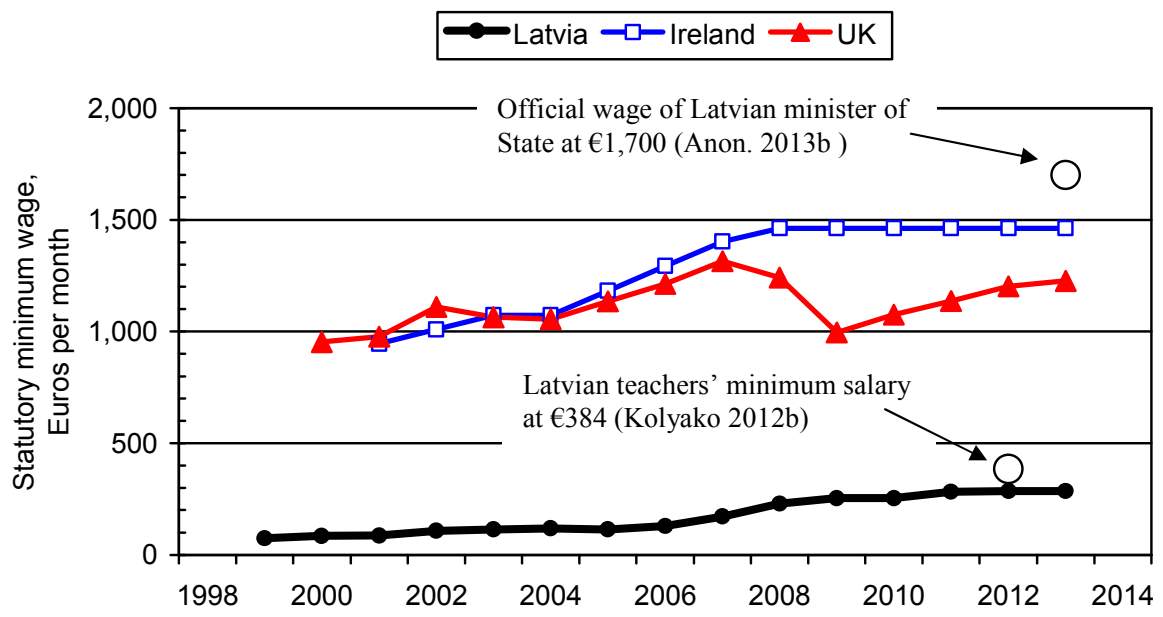

Source: EUROSTAT (2014) data

The much-touted austerity successes (Saltzmann 2012) and current economic recovery (Weisbrot and Ray 2011, Blanchard et al. 2013: European Commission 2013) do not address the fundamental underlying issue of causing continued mass emigration (Anon. 2012b, Sommers and Hudson 2013). Just like in Ireland, emigration hides the national jobless figures (Newenham 2012). In officialdom, the falling unemployment rate ignores the distorting statistics of mass exodus of unemployed people. The consolation of unrestricted emigration is that it has served (and continued to serve) as a "safety valve" in avoiding massive social unrest inside Latvia, in the absence of any apparent concerted effort to provide enduring employment, especially to the educated youth. Recent mass migration of Romanians to escape homeland poverty is a case in point (Meeus 2013). In the present day, it is the EU "free market" policy that will affect the fate of the Latvian demographic status in future years.

\section{Discussion: Remedial strategy for re-population}

It is obvious that if the death rate was fixed to be the same as the crude birth rate, the population would be stabilized, albeit at a low (or high) level. In this instance, any net increase could only arise from immigration of foreigners and/or re-immigration of recent Latvian émigrés. Unfortunately, Latvia is not a preferred destination of foreigners 
eager to immigrate, legally or illegally, to Europe. The destination of choice is typically prosperous Germany or the UK. It is a simple matter of economic opportunity. It follows that there have been very few immigrants granted Latvian citizenship during the past 2 decades (CSB 2014). The recent proposed change in citizenship law permits dual citizenship (Petrova 2012) with the plausible underlying aim to re-populate Latvia by the creation of new citizens of Latvian-ethnicity from Latvian expatriate communities. It is however unrealistic to expect that descendents of Latvians who had emigrated during the 1940 voluntary exodus (via Germany) would seek to return to re-settle in Latvia. Too much time and distance had transpired. In fact, very few the 1940-exodus group had actually returned to settle in Latvia permanently since the restoration of the Latvian Republic in 1990. For example, the number of USA citizens residing in Latvia has ranged only between 200 and 300 in each year between 1996 and $2013^{8}$ (CSB 2014) and yet USA has the largest Latvian expatriate community in the World. Patriotic and/ or cultural appeal to return to the Latvian homeland is of little or no practical attraction to Latvian expatriates living well in cash-based societies abroad. The overlay of this peculiar immigration outcome is the ever-present ethno-centric imperative of "preserving Latvia for pur laine $e^{9}$ Latvians". Such a type of sentiment is notably ubiquitous in many contemporary communities throughout Europe and elsewhere.

In comparison, Finland's population has been increasing with an influx of an average 9,000 immigrants annually during the 22 years between 1990 and 2012. The Finnish population has increased steadily, in view of declining low crude birth rate exceeding stabilized death rate by a small margin. Table 3 illustrates the comparative movement of migrants. According to the Finnish Red Cross (2010), the majority of immigrants accepted by Finland is from Estonia and Russia, at about the same proportion.

Table 3. Net migration comparison between Latvia and Finland

\begin{tabular}{|l|c|c|l|}
\cline { 2 - 3 } \multicolumn{1}{c|}{} & \multicolumn{2}{c|}{ Resident population } & \multicolumn{1}{c|}{} \\
\hline & 1990 & 2012 & $\begin{array}{l}\text { Estimated cumulative population change due to } \\
\text { migration, in 22 years }\end{array}$ \\
\hline Latvia & $2,668,140$ & $2,044,813$ & $-397,167(\sim 18,000$ emigrated annually $)$ \\
\hline Finland & $4,998,476$ & $5,426,674$ & $+196,415(\sim 9,000$ immigrated annually $)$ \\
\hline
\end{tabular}

Source: Adapted from CSB (2014) data; Statistics Finland (2014) data

The strategy of "stopping all emigration" alone does not provide sufficient reversal in population decline. Figure 13 shows that that the Estonian population continues to decline even though net migration has been zero for nearly a decade. The underlying issue is that the high death rate originating in the 1990s has yet to be reversed in Estonia, in view of the generally declining birth rate (cf. Figure 5). 
Figure 13. Continued decline of the Estonia population

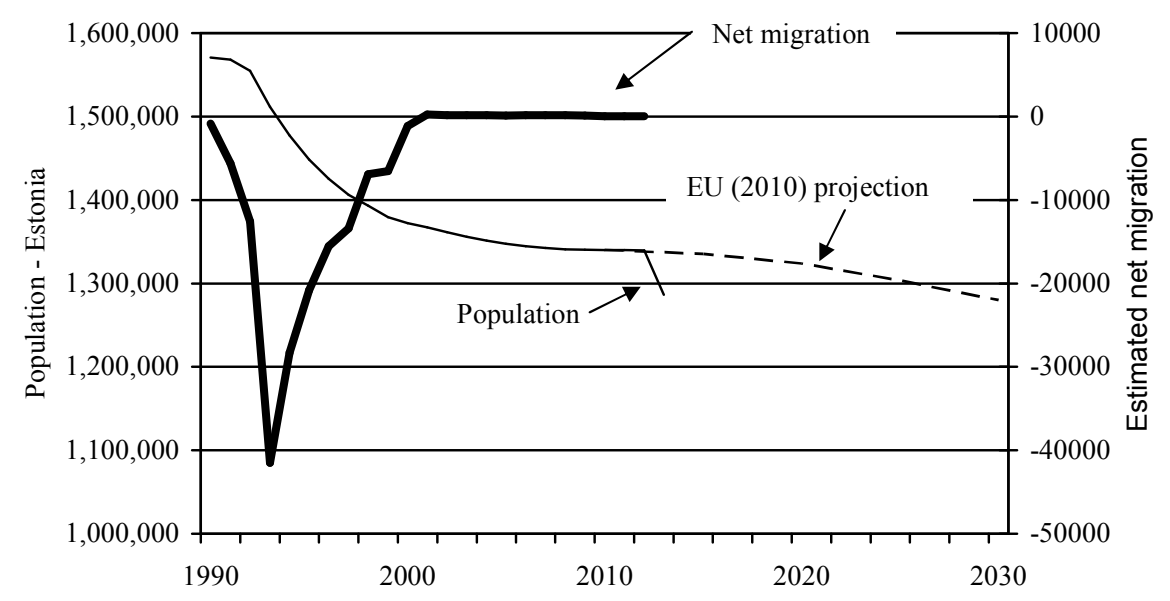

Source: Statistics Estonia (2014) data

Enhancing birth rate is a slow uncertain process of which the outcome is difficult to predict reliably or to realize practically, especially in industrialized countries. Indeed increasing the birth rate is very complex as it embodies many elements which could not be fostered by government financial economic incentives alone. See, for example, the sole objective of the very aggressive pro-birth policy of the Government of Singapore has remained largely unfulfilled since its promulgation in 1984 (Wong and Yeoh, 2003; Webb, 2006).

In a study of 8 Eastern European states, Leasure (1992) had hypothesized the growth of personal autonomy (i.e., increased personal control over economic and reproductive life) to be the factor responsible the decline in fertility. Other confounding factors of family formation include personal adaptation of instant hedonistic lifestyle and accumulation of ostentatious financial wealth, both of which are increasingly prevalent in contemporary "western culture". It follows that the classical method characterization of determinants of birth rate (syn., fecundity rate) such as that described by Heleniak (2010: 91) or the Two-Sex Model (Caswell 1989: Chapter 10) may be very problematic. The breeding behaviour of contemporary humans is unlike that of other animals.

Although the problem of ageing population (in the context of low birth rate) is outside the scope of the present study, some cursory comments are nevertheless pertinent in the framework of altering the demographic situation. For example, the undesired ageing of the population (arising from low birth rate) could however be fixed decisively by the method suggested by the Japanese Finance Minster in early 2013: "....Country should let old people hurry up and die" (Bennett-Smith, 2013). Alternatively, continuing economic support for the ageing population (with preservation of the prevailing culture) could be sustained by implementing a purposeful system of importing migrant 
workers only to fill available jobs in manufacturing, heath care, sanitation services, etc. As in the case of Abu Dhabi, Canada, Dubai, Hong Kong, Singapore and many other economically-wealthy countries, curtailment of basic human rights of (young) migrant workers would be strictly enforced. For example, wages of migrant workers could set "legally" low, no citizenship would ever be granted to migrant workers, and pregnancy among female migrant workers would be strictly prohibited (see, for example, Batty, 2013; Chonghaile, 2014; Gibson, 2014; Falconer and Kelly, 2015). As an efficient means to reduce welfare costs, Germany has been exporting its sick and elderly citizens to care homes in lower-cost Hungary and other Eastern European states (Connolly, 2012). For reasons of professed moral ethics, these example draconic approaches to solve the demographic problem of ageing population are rarely discussed openly.

In the case of Latvia, a possible remedy must be an aggressive coordinated repopulation program which prioritizes these three essential elements:

1. Repair the failures of the current modality of national health care. Improvements should include significant State assistance to provide better nutrition and adequatelyheated housing, among other things, for the population at large. As a means to reduce the national death rate (arising from all causes), the health and health care could be rectified readily by government fiat with appropriate funding. Certainly, access to better nutrition as exemplified by improved food affordability, and better housing with adequate heating during the colder months would be vital for the preventive health care of citizens. The outcome would lead to a substantial reduction in high premature death rate which in turn could provide significant almost instant gain in population count. In reference to the remarks given previously, improving health care does not necessarily require higher expenditure as in the case of Cuba where full-spectrum high quality health care is available unconditionally for all.

2. Create higher paying jobs in Latvia to entice prospective young emigrants to stay in Latvia. Appeal to national pride or national salvation only has a limited effect. Strazds has commented that emigration could be stopped by increasing the income to $70 \%$ of the EU average (Anon. 2013e). It is important to consider that reduction in emigration could not be achieved by just raising the income level alone. The economy could only be re-balanced if there was a concerted program to build a new style industrial base, in view of the historical sparse population density, highly educated work force, and abundance of natural resources. See, for example, community-scale development projects to create enduring jobs as described previously by Wong (2013).

3. Aim to repatriate, for example, about 4,000 Latvian émigrés per year for 8 years. This inflow would be equivalent to about $25 \%$ of the 20,469 net emigrants departed from Latvia annually during the past 8 years, i.e., from 2004 to 2012. This program 
of return could be achieved only if there were new higher-paying meaningful jobs available in Latvia. It is noted that there are appreciable repatriation uncertainties such as the participating age group and eventual propensity for family formation.

The projected outcome of four basic rectification strategies was constructed on the basis of assumptions given in Table 4. It is recognized application of simple historic percentages does not guaranteed a desired future outcome. Nevertheless, the present approach provides some practical guidelines about the future course of action required to rectify the present demographic crisis.

Table 4. Assumptions used in the remedial scenarios evaluated

\begin{tabular}{|c|l|l|l|}
\hline \multicolumn{4}{|c|}{2013 to 2020 inclusive } \\
\hline Scenario & \multicolumn{1}{|c|}{ Crude birth rate } & \multicolumn{1}{|c|}{ Death rate } & \multicolumn{1}{|c|}{ Apparent net migration } \\
\hline 1 & $\begin{array}{l}\text { Constant } 0.97 \% \text { of } \\
\text { population; same as in } \\
2012\end{array}$ & $\begin{array}{l}\text { Constant } 1.42 \% \text { of } \\
\text { population; same as in } 2012\end{array}$ & $\begin{array}{l}\text { Constant }-0.98 \% \text { of population; } \\
\text { same as in } 2012\end{array}$ \\
\hline 2 & $\begin{array}{l}\text { Constant } 0.97 \% \text { of } \\
\text { population; same as in } \\
2012\end{array}$ & $\begin{array}{l}\text { Constant } 1.42 \% \text { of } \\
\text { population; same as in } 2012\end{array}$ & Set to zero \\
\hline 3 & $\begin{array}{l}\text { Constant } 0.97 \% \text { of } \\
\text { population; same as in } \\
2012\end{array}$ & $\begin{array}{l}\text { Set to constant } 0.95 \% \text { of } \\
\text { population; same as the } \\
\text { 2012 level of Finland }\end{array}$ & Set to zero \\
\hline 4 & $\begin{array}{l}\text { Constant } 0.97 \% \text { of } \\
\text { population; same as in } \\
2012\end{array}$ & $\begin{array}{l}\text { Set to constant 0.95\% of } \\
\text { population; same as the } \\
\text { 2012 level of Finland }\end{array}$ & $\begin{array}{l}\text { Set to nominal }+5,000 \text { per year for } \\
8 \text { years* }\end{array}$ \\
\hline
\end{tabular}

* set arbitrarily to be equivalent to about $25 \%$ of the 20,469 net emigrants departed from Latvia annually in the 8 years since EU accession, i.e., from 2004 to 2012.

The "Scenario 1" population estimate for 2020 given in Figure 14 is about 100,000 higher than the 1.7 million suggested by Kazāks (2012). By stopping all emigration and not addressing the high death rate issue as per "Scenario 2" would be effective only in arresting the population decline moderately. In "Scenario 3" in which the death rate was re-set to the same level of that of Finland in 2012, i.e., $0.95 \%$ of population and zero net emigration, the decline in population could be stopped. Coincidentally, the death rate of $0.95 \%$ of population in Finland in 2012 is numerically similar to the crude birth rate of $0.97 \%$ of Latvian population in 2012 . If all three points of the proposed remedial program could be realized successfully, "Scenario 4" would be the best practicable approach to re-populate Latvia. There would be a small rise in the population over the short term of the next 8 years, without inclusion of the possible positive effect of higher birth rate among young repatriates. Larger net re-immigration (of recent émigrés) would be desirable, subject to the logistical re-settlement capacity of the State. It is interesting to note that the EU projection of Latvian population as shown in Figure 14 was already incorrect when the projection was first published in 2010. It appears that the European Commission did not consider the impact of emigration adequately in this instance. 
Figure 14. Forecasted outcome of different remedial scenarios

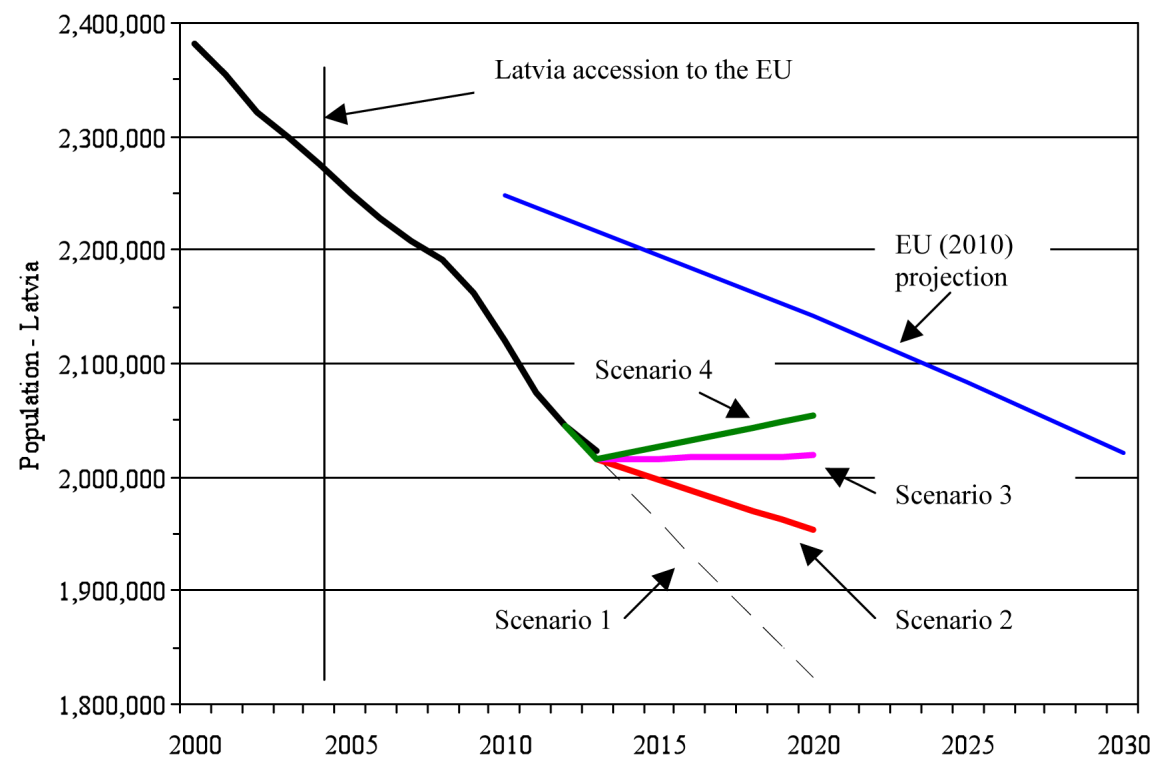

\begin{tabular}{|l|l|l|l|}
\hline Scenario* & $\begin{array}{l}\text { Crude birth rate, } \\
\% \text { of population }\end{array}$ & $\begin{array}{l}\text { Death rate, } \\
\% \text { of population }\end{array}$ & Migration \\
\hline 1 & $0.97 \%$ (in 2012) & $1.42 \%$ (in 2012) & $-0.98 \%$ of population (in 2012) \\
\hline 2 & $0.97 \%$ & $1.42 \%$ & Zero \\
\hline 3 & $0.97 \%$ & $0.95 \%$ & Zero \\
\hline 4 & $0.97 \%$ & $0.95 \%$ & $+5,000$ annual repatriation \\
\hline
\end{tabular}

* See Table 3 for additional details

\section{Concluding remarks}

The observed chaos arising from the 1990-1995 transition from the Latvian Soviet Socialist Republic to the Republic of Latvia has undoubtedly impacted the society to cause a continuing decline in population. In particular, the collapse of the State-sponsored social welfare, health care and economic structure has manifested in accelerated decline crude birth rate, substantial increase in death rate and mass emigration from Latvia. Aside from the Latvian situation, large post-1990 gap between lower crude birth rate and higher death rate was also found to be present in other former "Soviet states", viz., Estonia, Lithuania, Belarus, Russian Federation and Ukraine which are experiencing 
substantial decline in national population. The conclusion is similar if absolute number, instead of rate, of crude births and deaths was considered. It is recognized that births, deaths and emigration (or immigration) are interdependent from an age profile viewpoint. For example, mass emigration of young people would ultimately cause a decline in number of births in future years.

In the present projection, the Latvian population will continue its precipitous rapid decline over the next few decades if the underlying causes were not remedied. There is an urgent need for the Latvian State to act in a timely fashion with adequate cash input. The suggested 3-point program might comprise of improvement in health care (including nutrition and housing), creation of new higher paying jobs to entice Latvians to stay in their homeland, and repatriation of recently-emigrated Latvians from the wealthy EU states such as the UK and Germany. It is noted that some of these Latvian State interventions may be contrary to existing EU rules and regulations pertaining to, among other things, State aids. But the Latvian demographic crisis is a present and real danger, which warrants extraordinary remedial measures. Indeed special emergency funding should be allocated from the European Commission to undertake these urgent remedial tasks. Perhaps in the end, it might be reduced to a choice of defying the European Union and saving the Latvian nation. If no action is taken soon, there may be insufficient Latvians left to save the Latvian nation.

\section{References}

Ainsaar, M. (2011). Population changes, life expectancy and health. Chapter 2. In: M. Lauristin, ed., Estonian Human Development Report. Baltic way(s) of human development: Twenty years on. Tallinn: Eesti Koostöökogu.

Amiraux, V. \& Simon, P. (2006). There are no minorities here: Cultures of scholarship and public debate on immigrants and integration in France. International Journal of Comparative Sociology 47, 191-215.

Anon. (2012a). Latvia struggles with 'demographic disaster'. France 24 - France, 22 May. http:// www.france24.com/en/5325058 [accessed 11 Nov 2013].

Anon. (2012b). Latvia and Lithuania: a demographic disaster. The Socialist Voice - Ireland, No.94 (October), 2-3.

Anon. (2013a). Demographer: only few years left to prevent Latvian nation's extinction. The Baltic Course-Latvia, 21 February. http://www.baltic-course.com/eng/analytics/\&doc=70731 [accessed 26 Nov 2013].

Anon. (2013b). Vjaceslavs Dombrovskis sees Latvia as 'weak' country, which doesn't listen to entrepreneurs. The Baltic Course - Latvia, 30 April.

http://www.baltic-course.com/eng/direct_speech/\&doc=74146 [accessed 30 Apr 2013].

Anon. (2013c). Swedbank: Latvia's population may decrease to under $2 \mathrm{mln}$ in 2014. The Baltic Course - Latvia, 19 July. http://www.baltic-course.com/eng/analytics/\&doc=77958 [accessed 23 Aug 2013].

Anon. (2013d). Hazana: official migration data not in line with actual situation in Latvia. The Baltic Course - Latvia, 22 July. http://www.baltic-course.com/eng/analytics/\&doc=78062 [accessed 26 Nov 2013]. 
Anon. (2013e). Strazds: only increasing incomes to $70 \%$ of EU average will stop emigration from Latvia'. The Baltic Course - Latvia, 16 December. http://www.baltic-course.com/engdirect speech/\&doc=72344 [accessed 23 Mar 2013].

Anon. (2013f). Latvia on verge of extinction. Estonian World Review, 22 February. http://www.eesti.ca/latvia-on-verge-of-extinction/article38778 [accessed 26 Nov 2013].

Anon. (2014). Ghosts of WWII haunt Russia-Latvia relations. Russia Today, 13 May. http://rt.com/politics/russia-latvia-moscow-relations/ [accessed 16 Mar 2014].

Batty, D. (2013). Conditions for Abu Dhabi's migrant workers 'shame the west'. The Guardian UK, 22 December. http:/www.theguardian.com/world/2013/dec/22/abu-dhabi-migrant-workersconditions- shame-west [accessed 14 Feb 2014].

Behmane, M. (2011). Number of Latvian population during the 2011 will diminish by 23 thousand persons. The Baltic Course - Latvia, 16 December. http://www.baltic-course.com/eng/ interviews $/ \&$ doc $=48926$ [accessed 16 Dec 2011].

Bennett-Smith, M. (2013). Taro Aso, Japanese Finance Minister, says country should let old people 'Hurry Up And Die'. The Huffington Post, 23 January. http://www.huffingtonpost.com/2013/01/23/ taro-aso-japanese-finance-minister-old-people-hurry-up-die_n_2535184.html [accessed 06 Mar 2013].

Blanchard, O., Griffiths, M. \& Gruss, B. (2013). Boom, bust, recovery forensics of the Latvia crisis. Paper presented at the 2013 Brookings Panel on Economic Activity, Washington (DC), USA, 19-20 September.

Bongaarts, J. \& Sobotka, T. (2012). A demographic explanation for the recent rise in European fertility. Population and Development Review 38, 83-120.

Cahill, A. (2013). 400 a year trafficked for sham marriages. Irish Examiner - Ireland, 1 February. http:// www.irishexminaer.com/ireland/400-a-year-trafficked-for-sham-marriages [accessed 06 Feb 2013].

Caswell, H. (1989). Matrix Population Models: Construction, Analysis, and Interpretation. Sunderland (MA): Sinauer Associates, Inc.

Central Statistics Bureau - CSB (2014). Population Census. http://www.csb.gov.lv - Table ISG09. Population of Latvia by citizenship at the beginning of the year.

Chonghaile, C.N. (2014). Beaten, trapped, abused and underpaid - migrant domestic workers in the UAE. The Guardian - UK, 23 October. http://www.theguardian.com/global-development/2014/ oct//migrant-domestic-workers-uae-beaten-abused [accessed 12 Jan 2015].

Christiansen, E. (1997). The Northern Crusades. London: Penguin Books Ltd.

Clemens, W.C., Jr. (1991). Baltic Independence and Russian Empire. New York: St. Martin's Press.

Connolly, K. (2012). Germany 'exporting' old and sick to foreign care homes. The Guardian - UK, 26 December. http://www.theguardian.com/world/2012/dec/26/german-elderly-foreign-care-homes [accessed 31 Jan 2014].

European Commission (2013). EU BOP Assistance to Latvia-Second Review under Post-Programme Surveillance. 15 January. Brussels: Directorate General - Economic and Financial Affairs.

European Commission (2014). EU Anti-Corruption Report. Report from the Commission to the Council and the European Parliament. Report COM(2014) 38 final, 3 February. Brussels: Home Affairs, European Commission.

EUROSTAT (2014). Statistics. http://epp.eurostat.ec.europa.eu/

- TPS00001: Population at 1 January (adjusted since last census or based on population register).

- TPS00002: Population projection ('cohort-component' method used).

- TPS00155: Minimum wages (gross amount; enforced by law).

- TPS00175: Average gross annual earnings in industry and services (of full-time employees in enterprise with 10 or more employees; gross remuneration in cash paid directly before any deductions for income taxes and social security contributions paid by the employee). 
Falconer, R. \& Kelly, A. (2015). The global plight of domestic workers: few rights, little freedom, frequent abuse. The Guardian - UK, 17 March. http://www.theguardian.com/global-development $/ 2015 / \mathrm{mar} / 17 /$ global-plight-domestic-workers-labour-rights-little-freedom-abuse [accessed 30 Mar 2015].

Finnish Red Cross (2010). Platform for European Red Cross Cooperation on Refugees, Asylum Seekers and Migrants: Country Update 2010. http://www.ifrc.org/PageFiles/89645/Finland\%20 Country\%20Report\%20PERCO\%202010.pdf [accessed 01 Mar 2014].

Gibson, O. (2014). Paralysed in Qatar: Nepalese workers trapped in Kafkaesque Gulf nightmare. The Guardian - UK, 27 January. http://www.theguardian.com/world/2014/jan/27/nepalese-workersworld-cup-building-sites-qatar-left-paralysed [accessed 25 Mar 2014].

Göler,D., Krišjāne, Z. \& Bērziņš, M. (2014). International migration in the periods of transition and crisis: The case of Latvia. The Baltic Region 2(20), 97-110.

Grogan, L. (2006). Alcoholism, tobacco, and drug use in the countries of Central and Eastern and the former Soviet Union. Substance Use and Misuse 41, 567-571.

Hallsworth, A. \& Wong, A. (2016) Tyranny of corporate dominance exemplified by food supply in modern-day Britain. Journal of Law and Governance 10, 25-38.

Hecht, J. (1986). Politiques de population et action sure la natalité en Europe de l'Est (1ere partie). Politiques de population 2, 7-51.

Heleniak, T. (2010). Causes and demographic consequences of fertility decline in the former Soviet Union and Central and Eastern Europe. Marriage \& Family Review 46, 79-106.

Hoem, J.M. (2005). Why does Sweden have such high fertility? Demographic Research 13: 559-572. Ijabs, I. (2012a). The nation of the socialist intelligentsia: The national issue in the political thought of early Latvian socialism. East Central Europe 39, 181-203.

Ijabs, I. (2012b). Break out of Russia: Mikelis Valters and the National issue in early Latvian socialism. Journal of Baltic Studies 43, 437-458.

Ijabs, I. (2014). Another Baltic postcolonialism: Young Latvians, Baltic Germans, and the emergence of Latvian National Movement. Nationalities Papers 42, 88-107.

Kasekamp, A. (2010). A History of the Baltic States. New York: Palgrave Macmillan.

Katz, K. (2011). Fake marriage - a hugh problem for many Latvian women. Baltic Course - Latvia, 15 December. http://www.baltic-course.com/eng/interview/\&doc=50264 [accessed 16 Dec 2011]

Kazāks, M. (2012). Demography and its economic consequences in the Baltics: The case of Latvia. Discussion Paper No. 25, 8 October. Riga: Swedbank.

Kinder, H. \& Hilgemann, W. (1978). The Anchor Atlas of World History. Volume 1-From the Stone Age to the Eve of the French Revolution. Translated by E.A. Menze. Garden City (NY): Anchor Books.

Kõlves, K., Milner, A. \& Varnik, P. (2013). Suicide rates and socioeconomic factors in Eastern European countries after the collapse of the Soviet Union: Trends between 1990 and 2008. Sociology of Health and Illness 35, 956-970.

Kolyako, N. (2011a). Majority of Latvian job seekers interested in employment opportunities in Germany. The Baltic Course - Latvia, 22 July. http://www.baltic-course.com/eng/analytics/\&doc=43746 [accessed 22 Jul 2011].

Kolyako, N. (2011b). Hazans: another 100,000 people to emigrate from Latvia in 3-4 Years. The Baltic Course - Latvia, 21 November. http://www.baltic-course.com/eng/interviews/\&doc=48926 [accessed 16 Dec 2011].

Kolyako, N. (2012a). Demographers: Latvia first in Europe in terms of how little money the state spends on families. The Baltic Course - Latvia, 02 February http://www.baltic-course.com/eng/analytics/\&doc=52518 [accessed 02 Feb 2012].

Kolyako, N. (2012b). Teachers' minimum monthly salary to be raised to LVL 270. The Baltic CourseLatvia, 21 June. http://www.baltic-course.com/eng/education/\&doc=59047 [accessed 25 Jun 2012]. 
Kolyako, N. (2012c). Denins: at least 500,000 have left Latvia, similar to the post-war Period. The Baltic Course - Latvia, 13 August. http://www.baltic-course.com/eng/direct_speech/\&doc=61292 [accessed 14 Sep 2012].

Kūle, L. (2008). Future demographic trends in Latvia. VASAB notes. Riga: Vision \& Strategies around the Baltics (VASAB). http://www.vasab.org

Leasure, J.W. (1992). The historical decline of fertility in Eastern Europe. European Journal of Population 8, 47-75.

Lyulko, L. (2014). EU aid destroyed Portugal', Pravda - Russia, 18 March

http://english.pravada.ru/world/europe/18-03-2014/127129-eu_aid-o/ [accessed 22 Mar 2014].

Mackenbach, J.P. (2013). Political conditions and life expectancy in Europe, 1900-2008. Social Science and Medicine 82, 134-146.

Mackenbach, J.P., Hu, Y. \& Looman, C.W.N. (2013). Democraticization and life expectancy in Europe, 1960-2008. Social Science and Medicine 93, 166-175.

Meeus, B. (2013). Welfare through migrant work: What if the Romanian "safety valve" closes? Journal of Southeast European and Black Sea 13, 175-194.

Minagawa, Y. (2013). Inequalities in healthy life expectancy in Eastern Europe. Population and Development Review 39, 649-671.

Misunas, R.J. \& Taagepera, R. (1992). The Baltic States: Year of Dependence 1940-1990. London: Hurst\& Company.

Newenham, P. (2012). Emigration 'disguises jobless figures'. The Irish Times - Ireland, 6 December. http://www.irishtimes.com/newspaper/finance/2012/1206/ [accessed 26 Jan 2013].

Office of National Statistics - ONS (2013). Methodology used to produce the national population projections: Summary of Summary of cohort component method. http://www.ons.gov.uk/ons/guidemethod/method-quality/specific/population-and-migration/population-projections/methodology national-population-projections/index.html [accessed 10 Oct 2013].

Petrova, A. (2012). Latvian Parliament approves Citizenship Law amendments in second Reading. The Baltic Course - Latvia, 06 September. http://www.baltic-course.com/eng/legislation/?doc=62446 [accessed 20 Jan 2013].

Plakans, A. (2011). A Concise History of the Baltic States. Cambridge: Cambridge University Press.

Pabriks, A. \& Purs, A. (2002). Latvia: The challenges of change. In: D.J. Smith, A. Pabriks, A. Purs \& T. Lane, eds., The Baltic States: Estonia, Latvia and Lithuania. London: Routledge.

Pritchett, L. \& Viarengo, M. (2012). Why demographic suicide? The puzzles of European fertility. Population and Development Review 38(Supplement), 55-71.

Rejevska, F. (2005). Social policy in the Republic of Latvia during the transition period. Latvijas Universitātes Rakst 686, 79-92.

Rancans, E., Salander Renberg, E. \& Jacobsson, L.(2001). Major demographic, social and economic factors associated to suicide rates in Latvia 1980-98. Acta Psychiatrica Scandinavica 103, 275281.Rechel, B., Roberts, B., Richardson, E., Shishkin, S., Shkolnikov, V.M., Leon, D.A., Bobak, M., Karanikolos, M. \& McKee, M. (2013). Health and health systems in the Commonwealth of Independent States. The Lancet 381, 1145-1155.

Riasanovsky, N.V. (1984). A History of Russia. 4th Edition. Oxford: Oxford University Press.

Roudi-Fahimi, F. (2004). Islam and family planning. MENA Policy Brief. Washington (DC): Population Reference Bureau.

Saltzmann, M. (2012). The consequences of austerity in Latvia. World Socialist Web Site, 8 October. https://www.wsws.org/en/articles/2012/10/latv-o18.html [accessed 26 Nov 2013].

Sommers, J. \& Hudson, M. (2013). Latvia's economic disaster heralded as a neoliberal "success story": a model for Europe and the US?. The Baltic Course - Latvia, 08 January. http://www.baltic-course.com/eng/direct_speech/\&doc=68375 [accessed 14 Jan 2013].

Statistics Estonia (2014). Population. http://www.stat.ee

Statistics Finland (2014). Population. http://www.stat.fi/ 
Statistics Lithuania (2014). Population. http://www.stat.gov.lt

Strazds, A. \& Grennes, T. (2013). Population dynamics in the new EU member States: Unemployment matters much less than relative income levels. EconoMonitor, 27 June. http://www.economonitor.com/thoughtsacrossatlantic/2013/06/27 [accessed 26 Nov 2013].

Taagepera, R. (1981a). Baltic population changes, 1950-1980. Journal of Baltic Studies 12, 35-57.

Taagepera, R. (1981b). The population crisis and the Baltics. Journal of Baltic Studies 12, 234-244.

Transparency International (2013). Corruption Perception Index. Published annually. Berlin: Transparency International.

Várnik, A. (2012). Suicide in the former Soviet Union (USSR). In: A. Shrivastava, Kimbrell, M. \& Lester, D., eds., Suicide from a Global Perspective: Psychosocial Approaches. Hauppauge (NY): Nova Science Publishers.

Webb, S. (2006). Pushing for babies: Singapore fights fertility decline. Reuters, 26 April. http://www.singapore-window.org/sw06/060426re.htm [accessed 21 Jan 2014].

Weisbrot, M. \& Ray, R. (2011). Latvia's internal devaluation: A success story? Washington (DC): Center for Economic and Policy Research.

Wong, T. \& Yeoh, B.S.A. (2003). Fertility and the family: An overview of pro-natalist population policies in Singapore. Research Paper Series No. 12. Singapore: Asian Meta Centre for Population and Sustainable Development Analysis, National University of Singapore.

Wong, A. (2008). Incident solar radiation and coronary heart disease mortality rates in Europe. European Journal of Epidemiology 23, 609-614.

Wong, A. \& Gomes, R. (2012). Societal and economic elements of trafficking in human beings into the European Union. Etnoantropološki problemi 7, 831-852.

Wong, A. (2013). Establishment of a technology development bank as a means to facilitate economic development in rural Latvia. Proc. 12th International Scientific Conference "Engineering for Rural Development", Jelgava, Latvia, 23-24 May.

Wong, A. \& Hallsworth, A. (2013). Corporate subversion of social-justice initiatives on food and agriculture. Journal of Administration and Governance 8(1), 1-10.

Wong, A. \& Gomes, R. (2014). Corruption in modern-day Africa: a possible remedy. Journal of Pan-African Studies 7, 77-114.

Wong, A. \& Bradley, M. (2016). The effect of ethnological elements on the continuing Latvian demographic crisis. Forthcoming.

Zukula, B. (2013). In 2000-2010, population in Latvia diminished by 307 thousand or by $12.9 \%$. The Baltic Course - Latvia, 14 March. http://www.baltic-course.com/eng/analytics/\&doc=71882 [accessed 14 Mar 2013].

Zvidrins, P. (2009). Depopulation in the Baltic States. Proc. XXVI International Population Conference. International Union for the Scientific Study of Population, Marrakech, Morocco, 27 September - 2 October. http://iussp2009.princeton.edu/papers/91919 [accessed 15 Nov 2013]. 


\section{Notes}

1 European Union at 27 member states

2 The invasion was completed in mid-1941.

3 For example, in an epidemiological study of coronary heart disease mortality (CHD) rate in Europe, Wong (2008) had intimated that France may have manipulated the mid-1980 CHD data surreptitiously for the national promotion of the "French Paradox", i.e., for the purpose of boosting the foreign sale and consumption of (French) red wine for better human health.

4 By law, French population census is not permitted to collect information on race or ethnicity. The exact figure is largely unknown. See, for example, Amiraux and Simon (2006).

5 Morally sinful, thus prohibited in Islamic jurisprudence.

6 Qur'an, Sūra 4 (An-Nisā), ayat 29: ......nor kill (destroy) yourselves: for verify Allah hath been to you most Merciful. (The Holy Qur'an, translated from Arabic to English by Abdullah Yusuf Ali, 1934). The prohibition of suicide has also been recorded in statements of hadith (reported deeds and sayings of the Prophet Muhammad made during his life time).

7 Non-citizens are those persons who have been refused citizenship by the Latvian state because of the lack of Latvian language proficiency.

8 The last year before the new 2012 Dual Citizenship Law comes into effect.

9 Pur laine, n. (in Quebec) a person belonging to a long-established family of French descent [French, literally: pure wool]..........Collins English Dictionary, 2003. 
